\title{
When a paradigm becomes a paradogma
}

\author{
Citation for published version (APA):
}

Kirschner, P. A. (2014). When a paradigm becomes a paradogma. Journal of Computer Assisted Learning, 30(4), 297-299. https://doi.org/10.1111/jcal.12074

DOI:

10.1111/jcal.12074

Document status and date:

Published: 04/07/2014

Document Version:

Peer reviewed version

Please check the document version of this publication:

- A submitted manuscript is the version of the article upon submission and before peer-review. There can be important differences between the submitted version and the official published version of record. People interested in the research are advised to contact the author for the final version of the publication, or visit the DOI to the publisher's website.

- The final author version and the galley proof are versions of the publication after peer review.

- The final published version features the final layout of the paper including the volume, issue and page numbers.

Link to publication

\section{General rights}

Copyright and moral rights for the publications made accessible in the public portal are retained by the authors and/or other copyright owners and it is a condition of accessing publications that users recognise and abide by the legal requirements associated with these rights.

- Users may download and print one copy of any publication from the public portal for the purpose of private study or research.

- You may not further distribute the material or use it for any profit-making activity or commercial gain

- You may freely distribute the URL identifying the publication in the public portal.

If the publication is distributed under the terms of Article 25fa of the Dutch Copyright Act, indicated by the "Taverne" license above, please follow below link for the End User Agreement:

https://www.ou.nl/taverne-agreement

Take down policy

If you believe that this document breaches copyright please contact us at:

pure-support@ou.nl

providing details and we will investigate your claim.

Downloaded from https://research.ou.nl/ on date: 26 Apr. 2023 


\section{Journal of Computer Assisted Learning}

\section{When a paradigm becomes a paradogma}

Every science, every scientific discipline, operates under one or more paradigms; a world view that underlies the theories and methodologies of the discipline. Sometimes a discipline's paradigms complement or supplement each other while at other times they may contradict or even exclude each other. While paradigms are strong and have longevity, they are also fluid, relative and changeable and can even 'die'. An anathema of the sciences, scientific disciplines and the process of carrying out science (or as Derek Hodson $^{1}$ calls it: 'doing science') is the dogma. In contrast to a paradigm, a dogma is a set of principles or a doctrine prescribed by an authority as incontrovertibly true. Dogmata are possibly most often found in religion, forming the core principles that must be upheld by all believers of a religion. As such, dogmata are also strong and have longevity, but are static, immutable and almost unchangeable except by divine decree. This editorial discusses a recent case which I and some colleagues encountered where a highly reputable scientific journal's editorial decision was not based on the article's quality (e.g., weak theory, bad methodology, improper statistics, ...) or misuse of a scientific paradigm (e.g., a methodology that does not fit the paradigm used), but rather on a dogma (i.e., the author questioned something that one of the executive editors found to be incontrovertibly true). In other words, a rejection based on a paradigm that has reached the status of a dogma; a paradogma.

As chief editor of one journal (this one) and associate editor of another, I get to see many different manuscripts running the gamut from small-scale laboratory experiments to large-scale ecologically valid experiments in schools; from rigorously controlled intervention studies for confirming/rejecting hypotheses to broad questionnaire cohort studies which are looking for relationships. The usual procedure for an incoming manuscript is that I and my associate editor first check to see whether the manuscript fits the Aims and Scope of the journal. If that is not the case I do not send it out for review, but rather reject it as quickly as possible as being 'Out of Scope' so as not to burden the author with waiting for a review that will not come. For example, an article for this journal should be about computer assisted learning. If the computer does not play a prominent or integral role in the research and if the research does not measure learning in one form or another, then it falls outside the scope of $J C A L$ and will be quickly rejected as being out of scope. This rejection has nothing to do with the quality of the manuscript! If we determine that a submitted manuscript falls within the scope of the journal, one or both of us then carry out a quick 'diagonal reading' of the manuscript to see if everything is technically in order. This technical check ranges from looking to see if the submitted manuscript is really an article or whether it is more a paper that would normally be found in the proceedings of a conference, to determining if the methodology used is sound for both the research that was carried out and the claims that the author or authors are making, to the quality of the language and the format of the text. Finally, if the manuscript passes all of these 'tests', we then try to choose the best reviewers for the manuscript based upon what the article is about and the expertise of the reviewers and then let them do their job. If they deem it worthy of publication (usually after one or two rounds of revision) it will be published online and physically as quickly as possible, and if it does not, then I reject it and tell the author/authors exactly why.

The journals that I edit, I am a board member of and I review for (about a dozen at the moment) publish a strikingly eclectic array of research. The research can be based on behaviourist, cognitivist and/or (social) constructivist learning paradigms; can make use of quantitative, qualitative and/or mixed-methods approaches to the research; may have been carried out in a laboratory, a school, a museum and/or commercial workplaces; their design can be experimental, quasiexperimental or design based; and so forth. What is never an issue is the scientific paradigm that the author has chosen to use. 